\title{
Fire risk assessment on hammer mill machine with human reliability assessment (HRA) and component reliability approaches
}

\author{
Khariza Amalia ${ }^{1, *}$, Haidar Natsir Amrullah ${ }^{2}$, Arief Subekti ${ }^{2}$, Moch. Luqman Ashari ${ }^{2}$, Edy \\ Prasetyo Hidayat ${ }^{3}$, Urip Mudjiono ${ }^{3}$ and Hendro Agus Widodo ${ }^{3}$ \\ ${ }^{1}$ Student, Safety Engineering, Shipbuilding Institute of Polytechnic Surabaya, 60111 Surabaya, \\ Indonesia \\ ${ }^{2}$ Safety Engineering, Shipbuilding Institute of Polytechnic Surabaya, 60111 Surabaya, Indonesia \\ ${ }^{3}$ Power Electrical Engineering, Shipbuilding Institute of Polytechnic Surabaya, 60111 Surabaya, \\ Indonesia
}

\begin{abstract}
In the animal feed industry, hammer mill machinery plays an important role in the smashing of raw materials. By 2017, in an animal feed industry there has been a fire on the dust collector that almost burned down the hammer mill machine. In previous years also often occur sparks arising due to the knife rubbing against the metal that carried away with raw material. However, the fire will not increase if the hammer mill machine operators are competent in extinguishing the fire. The purpose of this study is to find out how much the effects of hammer mill machine fire fighting in terms of safety scenarios that exist either from human procedures or automatic safety procedures performed by existing safety devices. In this study, using a combination of calculations between Human Error Probability (HEP) values obtained from Human Reliability Assessment (HRA) calculations using SPAR-H method and reliability calculation of hammer mill machine components obtained from downtime data for four years, 2014 until 2017. The total probability of outcome fire controlled increases from 0.177940 to 0,6393 and the total probability of outcome fire uncontrolled decreases from 0,82206 to 0,36068 .
\end{abstract}

\section{Introduction}

In our industrial world, safety and occupational health are very important aspects. An accident that afflict to workers and production machines that occur during production in an industry can cause a disturbance in the work and moreover can stop the production.

Based on previous research, it discusses about fire risk assessment which is reviewed from fire emergency response scenario from existing safety device side [1][2][3]. And based on other previous studies, it discusses about human error in work accidents using SPAR-H method. In this study only discussed about human error that can lead to work accident [4][5][6]. However, fire risk assessment research above has a weakness, it is not

\footnotetext{
*Corresponding author: kharizamalia@gmail.com
} 
considering from human error side, and human error research above only consider the human error side without considering the tool reliability. Whereas according to Heinrich (1980) on the domino theory of accident causation said that $80 \%$ of work accident happened because unsafe acts that come from humans and the remaining $20 \%$ caused by unsafe condition derived from engine components or machines that are not reliable. This study combines two approaches based on Heinrich theory i.e. component reliability and human error in the safety procedure scenario in case of fire. The probability of the existing safety device is calculated from the failure data that owned by the company, while the work that performed by the worker will be calculated using Human Reliability Assessment (HRA) with SPAR-H method. Then, calculated the probability value of each outcome. The purpose of this study is to determine how much the influences of unreliable components and human error in a fire incident, especially in the fire of hammer mill machine.

\section{Methodology}

\subsection{Fault Tree Analysis (FTA)}

Fault tree analysis (FTA) is a systems analysis technique used to determine the root causes and probability of occurrence of a specified undesired event [7].

Fig. 1. Single AND Gate

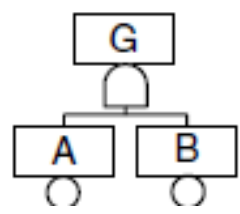

The formula to calculate the AND gate logic is as follow [7]:

$P=P A . P B=P A P B(2$ input gate)

$P=P A . P B \cdot P C=P A P B P C$ (3 input gate)

Fig. 2. Single OR Gate

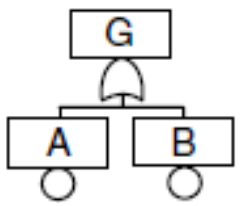

The formula to calculate the AND gate logic is as follow [7]:

$P=P_{A}+P_{B}-P_{A} P_{B}(2$ input gate)

$P=\left(P_{A}+P_{B+} P_{C}\right)-P_{A B} P_{A C} P_{B C}$ (3 input gate)

\subsection{Reliability Probability Distribution}

The MTTF (Mean Time to Failure) value and the MTTR (Mean Time to Repair) value is obtained using several formulas, depending on the distribution type on the data. Some common distributions used to calculate the reliability of equipments are shown as below [8]:

1. Normal Distribution

$$
M T T F=\mu
$$


2. Weibull Distribution

Weibull 2

$$
\text { MTTF }=\eta \Gamma\left(1+\frac{1}{\beta}\right)
$$

Weibull 3

$$
M T T F=t_{0}+\eta \Gamma\left(1+\frac{1}{\beta}\right)
$$

3. Lognormal Distribution

$$
\text { MTTF }=\exp \left(\mu+\frac{\sigma^{2}}{2}\right)
$$

4. Exponensial Distribution

$$
M T T F=\frac{1}{\lambda}
$$

5. Reliability Function

$$
\begin{aligned}
& R(t)=\mathrm{e}-\lambda t \\
& \lambda=\frac{1}{M T B F} \\
& M T B F=M T T F+M T T R
\end{aligned}
$$

$\lambda$ : Constant failure rate

$\mathrm{t}:$ The time value of a component works

6. Failure Probability

$$
P(t)=1-R(t)
$$

\subsection{HRA with SPAR-H Method}

A HRA is an in depth assessment of a system's risk level as a function of human performance [9]. The Standardized Plant Analysis Risk (SPAR) Human Reliability Analysis (HRA) method is as implified HRA approach intended to be used in conjunction with the development of SPAR probabilistic risk assessment (PRA) models.

\subsubsection{Determining the PSF value}

SPAR-H method calculates HEP (Human Error Probability) based on PSF's (Performance Shaping Factors) in the SPAR-H method is as follow [10]:

Table 1 Performance Shaping Factor (PSF)

\begin{tabular}{|c|l|c|}
\hline $\begin{array}{c}\text { SPAR-H } \\
\text { PSF's }\end{array}$ & SPAR_H PSF Levels & $\begin{array}{c}\text { SPAR-H } \\
\text { Multipliers }\end{array}$ \\
\hline \multirow{5}{*}{$\begin{array}{c}\text { Available } \\
\text { Time }\end{array}$} & Inadiquate Time & $\begin{array}{c}\text { P (failure) }= \\
1.0\end{array}$ \\
\cline { 2 - 3 } & $\begin{array}{l}\text { Time available = time } \\
\text { required }\end{array}$ & 10 \\
\cline { 2 - 3 } & Nominal Time & 1 \\
\cline { 2 - 3 } & $\begin{array}{l}\text { Time available }>5 \mathrm{x} \\
\text { time required }\end{array}$ & 1 \\
\cline { 2 - 3 } & $\begin{array}{l}\text { Time available }>50 \mathrm{x} \\
\text { time required }\end{array}$ & 0.01 \\
\hline \multirow{2}{*}{$\begin{array}{c}\text { Stress / } \\
\text { stressors }\end{array}$} & Extreme & 5 \\
\cline { 2 - 3 } & High & 2 \\
\cline { 2 - 3 } & Nominal & 5 \\
\hline \multirow{2}{*}{} & Highly complex & 1 \\
\cline { 2 - 3 } & &
\end{tabular}




\begin{tabular}{|c|l|c|} 
Complexity & Moderately complex & 2 \\
\cline { 2 - 3 } & Nominal & 1 \\
\hline \multirow{3}{*}{$\begin{array}{c}\text { Experience } \\
\text { training }\end{array}$} & Low & Nominal \\
\cline { 2 - 3 } & High & 1 \\
\hline \multirow{4}{*}{ Procedures } & Not available & 0.5 \\
\cline { 2 - 3 } & Incomplete & 50 \\
\cline { 2 - 3 } & Available, but poor & 20 \\
\cline { 2 - 3 } & Nominal & 5 \\
\hline \multirow{3}{*}{$\begin{array}{c}\text { Ergonomics } / \\
\text { HMI }\end{array}$} & Missing/missleading & 1 \\
\cline { 2 - 3 } & Poor & 50 \\
\cline { 2 - 3 } & Nominal & 10 \\
\cline { 2 - 3 } & Good & 1 \\
\hline \multirow{2}{*}{$\begin{array}{c}\text { Fitness for } \\
\text { Duty }\end{array}$} & Unfit & 1.0 \\
\cline { 2 - 3 } & Degraded Fitness & 5 \\
\cline { 2 - 3 } & Nominal & 1 \\
\hline \multirow{3}{*}{ Work Process } & Poor & 2 \\
\cline { 2 - 3 } & Nominal & 1 \\
\cline { 2 - 3 } & Good & 0.8 \\
\hline
\end{tabular}

Once the assessment is decided on for each factor, then the next step calculates the human error

probabilities (HEP). The HEP calculation divides activities into two types, which are diagnosis activities and action activities. On diagnosis activities the value of failure probabilities is 0.01 and on action activities the value of failure probabilities is 0.001 The formula to calculate the HEP is as follow [10] :

HEP $=$ Time $x$ Stress $x$ Complexity $x$ Experience $x$ Procedure $x$ Ergonomics $x$ Fitness for Duty $x$ Work of Process

The formula to calculate HEP of diagnosis or actions activities is as follow [10]

$H E P_{\text {(diagrosis or act })}=\frac{N H E P_{x} P S F_{\text {composite }}}{N H E P\left(P S F_{\text {composite }}-1\right)}+1$

The formula to calculate HEP of diagnosis activities and actions activities is as follow [10] :

$$
\begin{gathered}
H E P_{(\text {actions +diugnosis) }}=H E P_{(\text {actions })}+ \\
H E P_{(\text {diagnosis })}-\left[H E P_{(\text {artions })} \times H E P_{(\text {diagnosis })}\right]
\end{gathered}
$$

SPAR-H method also incorporates the impact that failure of one task will have on an entire range of the work tasks; this is called dependency. Table 2 shows the dependency SPAR-H method [10].

Table 2. SPAR-H Dependency

\begin{tabular}{|c|c|c|c|c|c|}
\hline No & Crew & Time & Location & Cues & Dependency \\
\hline 1 & $\mathrm{~S}$ & $\mathrm{C}$ & $\mathrm{S}$ & $\mathrm{Na}$ & Complete \\
\hline 2 & $\mathrm{~S}$ & $\mathrm{C}$ & $\mathrm{S}$ & $\mathrm{A}$ & Complete \\
\hline 3 & $\mathrm{~S}$ & $\mathrm{C}$ & $\mathrm{D}$ & $\mathrm{Na}$ & High \\
\hline 4 & $\mathrm{~S}$ & $\mathrm{C}$ & $\mathrm{D}$ & $\mathrm{A}$ & High \\
\hline 5 & $\mathrm{~S}$ & $\mathrm{Nc}$ & $\mathrm{S}$ & $\mathrm{Na}$ & High \\
\hline 6 & $\mathrm{~S}$ & $\mathrm{Nc}$ & $\mathrm{S}$ & $\mathrm{A}$ & Moderate \\
\hline 7 & $\mathrm{~S}$ & $\mathrm{Nc}$ & $\mathrm{D}$ & $\mathrm{Na}$ & Moderate \\
\hline 8 & $\mathrm{~S}$ & $\mathrm{Nc}$ & $\mathrm{D}$ & $\mathrm{A}$ & Low \\
\hline 9 & $\mathrm{D}$ & $\mathrm{C}$ & $\mathrm{S}$ & $\mathrm{Na}$ & Moderate \\
\hline 10 & $\mathrm{D}$ & $\mathrm{C}$ & $\mathrm{S}$ & $\mathrm{A}$ & Moderate \\
\hline
\end{tabular}




\begin{tabular}{|c|c|c|c|c|c|}
\hline 11 & $\mathrm{D}$ & $\mathrm{C}$ & $\mathrm{D}$ & $\mathrm{Na}$ & Moderate \\
\hline 12 & $\mathrm{D}$ & $\mathrm{C}$ & $\mathrm{D}$ & $\mathrm{A}$ & Moderate \\
\hline 13 & $\mathrm{D}$ & $\mathrm{Nc}$ & $\mathrm{S}$ & $\mathrm{Na}$ & Low \\
\hline 14 & $\mathrm{D}$ & $\mathrm{Nc}$ & $\mathrm{S}$ & $\mathrm{A}$ & Low \\
\hline 15 & $\mathrm{D}$ & $\mathrm{Nc}$ & $\mathrm{D}$ & $\mathrm{Na}$ & Low \\
\hline 16 & $\mathrm{D}$ & $\mathrm{Nc}$ & $\mathrm{D}$ & $\mathrm{A}$ & Low \\
\hline 17 & & & & & Zero \\
\hline
\end{tabular}

S : Same

d : Different

c : Close

a : There is procedure

nc : Not close

Once the level of dependency is decided, the next step will be calculate the HEP based on dependency

a. On complete dependency the value of HEP is 1

b. On high dependency the value of HEP is

$$
H E P=\frac{\left(1+\frac{P_{W}}{O d}\right)}{2}
$$

c. On moderate dependency the value of HEP is

$$
H E P=\left(\frac{1+\left(6 x \frac{P w}{o d}\right)}{7}\right)
$$

d. On low dependency the value of HEP is

$$
H E P=\frac{1+\left(19 x \frac{P w}{o d}\right)}{20}
$$

e. On zero dependency the value of HEP is

$$
H E P=\frac{P w}{o d}
$$

Pw/od value is obtained from:

$$
\frac{P_{w}}{o d}=H E P \text { diagnosis }+H E P \text { action }
$$

\subsection{Event Tree Analysis (ETA)}

Event tree analysis (ETA) is an analysis technique for identifying and evaluating the sequence of events in a potential accident scenario following the occurrence of an initiating event [7]. The ETA technique can be used to model an entire system, with analysis coverage given to subsystems, assemblies, components, software, procedures, environment, and human error [7].

\section{Results and Discussion}

\subsection{Fault Tree Analysis (FTA)}




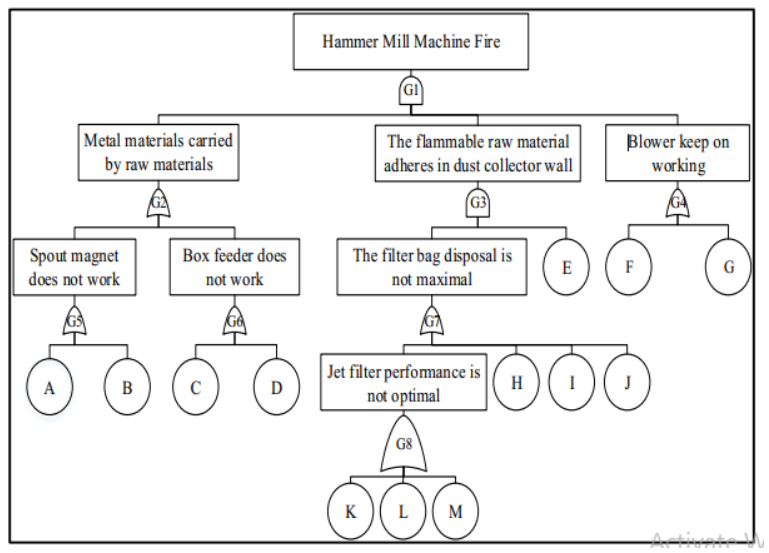

Fig. 3. Fault tree graph of hammer mill machine fire

The following is the symbols and meanings of hammer mill machine fire fault tree :

A : The magnetic plate full of metal

B : Magnetic force decreases

C : Box feeder full of material

$\mathrm{D}$ : Box feeder trouble

E : The blower interrupted

$\mathrm{F}$ : Temperatur safety interlock system trouble

$\mathrm{G}$ : Breaker of motor blower is not work

$\mathrm{H}$ : Filter bag is clogged

I : Filter bag rubber less binding

$\mathrm{J}$ : Filter bag membrane is torn

$\mathrm{K}$ : Solenoid valve has an error

$\mathrm{L}$ : Less air pressure

$\mathrm{M}:$ Air hose is broke

The minimum cut-set calculation of hammer mill machine fire is as follow :

$\mathrm{G} 1=\mathrm{G} 2 \cdot \mathrm{G} 3 . \mathrm{G} 4$

$\mathrm{G} 1=(\mathrm{G} 5+\mathrm{G} 6) \cdot(\mathrm{G} 7 \cdot \mathrm{E}) \cdot(\mathrm{F}+\mathrm{G})$

$\mathrm{G} 1=((\mathrm{A}+\mathrm{B})+(\mathrm{C}+\mathrm{D})) \cdot((\mathrm{G} 8+\mathrm{H}+\mathrm{I}+\mathrm{J}) \cdot \mathrm{E}) \cdot(\mathrm{F}+\mathrm{G})$

$\mathrm{G} 1=((\mathrm{A}+\mathrm{B})+(\mathrm{C}+\mathrm{D})) \cdot(((\mathrm{K}+\mathrm{L}+\mathrm{M})+\mathrm{H}+\mathrm{I}+\mathrm{J}) \cdot \mathrm{E}) \cdot(\mathrm{F}+\mathrm{G})$

$\mathrm{G} 1=((\mathrm{A}+\mathrm{B})+(\mathrm{C}+\mathrm{D})) \cdot(\mathrm{EK}+\mathrm{EL}+\mathrm{EM}+\mathrm{EH}+\mathrm{EI}+\mathrm{E} J) \cdot(\mathrm{F}+\mathrm{G})$

$\mathrm{G} 1=\mathrm{AEFK}+\mathrm{AEFL}+\mathrm{AEFM}+\mathrm{AEFH}+\mathrm{AEFI}+\mathrm{AEFJ}+\mathrm{A}$

$\mathrm{EGK}+\mathrm{AEGL}+\mathrm{AEGM}+\mathrm{AEGH}+\mathrm{AEGI}+\mathrm{AEGJ}+\mathrm{BEFK}+\mathrm{BEFL}+\mathrm{BEFM}+\mathrm{BEFH}+\mathrm{BEFI}+\mathrm{BEFJ}$

$\mathrm{BEG} \mathrm{K}+\mathrm{BEGL}+\mathrm{BEGM}+\mathrm{BEGH}+\mathrm{BEGI}+\mathrm{BEGJ}+\mathrm{CEFK}$

Table 3. Distribution Test Result of TTF and TTR Value of Hammer Mill Machine Components

\begin{tabular}{|c|c|c|c|c|c|c|c|}
\hline $\mathrm{No}$ & Component & Distribution & Explanation & MTTF & MTTR & MTBF & $\lambda$ \\
\hline \multirow[b]{2}{*}{1} & \multirow[b]{2}{*}{ Magnetic Plate } & Normal & TTF & \multirow[b]{2}{*}{3729,56} & \multirow[b]{2}{*}{0,50} & \multirow[b]{2}{*}{3730,05} & \multirow[b]{2}{*}{0,00027} \\
\hline & & Weibull 3 & TTR & & & & \\
\hline \multirow{2}{*}{2} & \multirow{2}{*}{ Box Feeder } & Weibull 2 & TTF & \multirow{2}{*}{3538,22} & \multirow{2}{*}{0,88} & \multirow{2}{*}{3539,10} & \multirow{2}{*}{0,00028} \\
\hline & & Weibull 3 & TTR & & & & \\
\hline \multirow{2}{*}{3} & \multirow{2}{*}{ Blower } & Lognormal & TTF & \multirow{2}{*}{7143,28} & \multirow{2}{*}{0,64} & \multirow{2}{*}{7143,92} & \multirow{2}{*}{0,0001} \\
\hline & & Weibull 3 & TTR & & & & \\
\hline \multirow{2}{*}{4} & \multirow{2}{*}{$\begin{array}{l}\text { Temperature Safety } \\
\text { Interlock System }\end{array}$} & Lognormal & TTF & \multirow[t]{2}{*}{7448,16} & \multirow[t]{2}{*}{1,29} & \multirow[t]{2}{*}{7449,45} & \multirow[t]{2}{*}{0,00013} \\
\hline & & Weibull 3 & $\overline{\text { TTR }}$ & & & & \\
\hline \multirow{2}{*}{5} & \multirow{2}{*}{ Breaker } & Weibull 2 & TTF & \multirow{2}{*}{6454,08} & \multirow{2}{*}{0,88} & \multirow{2}{*}{6454,96} & \multirow{2}{*}{0,00015} \\
\hline & & Weibull 2 & TTR & & & & \\
\hline \multirow{2}{*}{6} & Dust & Lognormal & TTF & \multirow[t]{2}{*}{8499,24} & \multirow[t]{2}{*}{0,49} & \multirow[t]{2}{*}{8499,73} & \multirow[t]{2}{*}{0,00012} \\
\hline & Membrane Rubber & Weibull 3 & TTR & & & & \\
\hline
\end{tabular}




\begin{tabular}{|c|c|c|c|c|c|c|c|}
\hline \multirow{2}{*}{7} & Filter & Lognormal & TTF & \multirow{2}{*}{10190648,1} & \multirow{2}{*}{0,87} & \multirow{2}{*}{10190648,97} & \multirow{2}{*}{0,000000098} \\
\hline & Membrane & Weibull 3 & TTR & & & & \\
\hline \multirow{2}{*}{8} & Jet Filter & Weibull 2 & TTF & \multirow{2}{*}{5630,20} & \multirow{2}{*}{0,91} & \multirow{2}{*}{5631,11} & \multirow{2}{*}{0,00018} \\
\hline & & Weibull 3 & $\begin{array}{l}\text { TTR } \\
\end{array}$ & & & & \\
\hline
\end{tabular}

Table 4. Calculation Result of Failure Rate, Reliability, and Probability Value of Hammer Mill Machine Components

\begin{tabular}{|c|c|c|c|c|}
\hline No & Component & $\lambda$ & $\mathrm{R}$ & $\mathrm{P}$ \\
\hline 1 & Magnetic Plate & 0,00027 & 0,1782 & 0,8218 \\
\hline 2 & Box Feeder & 0,00028 & 0,1672 & 0,8328 \\
\hline 3 & Blower & 0,00014 & 0,4089 & 0,5911 \\
\hline 4 & $\begin{array}{l}\text { Temperature } \\
\text { Safety Interlock } \\
\text { System }\end{array}$ & 0,00013 & 0,4358 & 0,5642 \\
\hline 5 & Breaker & 0,00015 & 0,3836 & 0,6164 \\
\hline 6 & $\begin{array}{l}\text { Dust Filter } \\
\text { Membrane } \\
\text { Rubber }\end{array}$ & 0,00012 & 0,4646 & 0,5354 \\
\hline 7 & $\begin{array}{l}\text { Dust Filter } \\
\text { Membrane }\end{array}$ & $\begin{array}{c}0,0000000 \\
98 \\
\end{array}$ & 0,9994 & 0,0006 \\
\hline 8 & Jet Filter & 0,00018 & 0,3167 & 0,6833 \\
\hline
\end{tabular}

$+\mathrm{CEFL}+\mathrm{CEFM}+\mathrm{CEFH}+\mathrm{CEFI}+\mathrm{CEFJ}+\mathrm{CE}+\mathrm{CEGK}+\mathrm{CEGM}+\mathrm{CEGH}+\mathrm{CEGI}+\mathrm{CEGJ}+\mathrm{DEFK}+$ $\mathrm{DEFL}+\mathrm{DEFM}+\mathrm{DEFH}+\mathrm{DEFI}+\mathrm{DEFJ}+\mathrm{DEGK}+\mathrm{DEGL}+\mathrm{DEGM}+\mathrm{DEGH}+\mathrm{DEGI}+\mathrm{DEGJ}$ set.

The minimum cut set calculation of hammer mill machine fire obtained 48 minimal cut

The explanation of the minimum cut set can be explained by an example of a minimum cut set of hammer mill machine fire is AEFK which is a magnetic plate full of metal, blower interrupted, temperature safety interlock system trouble, and solenoid valve has an error can be a direct cause of fire without supports from other basic events.

\subsection{Determine the Distribution and Component Failure Rate Calculation}

Weibull ++ version 6 software is applied to assess and process the downtime data in determining the type of distribution on the failures. The output of the software will result the parameter distribution that can be used to determine the interval time of the broken component(MTTF), interval time to repair the broken component (MTTR) and its reliability. Distribution test result of TTF and TTR value of hammer mill machine components with Weibull ++ version 6 software can be

Table 5 Probability Calculation of Bottom Level Fault Tree Hammer Mill Machine Fire

\begin{tabular}{|c|c|c|c|c|c|}
\hline No & Event & $\begin{array}{c}\text { Compo- } \\
\text { nent }\end{array}$ & $\begin{array}{c}\text { Sym- } \\
\text { bol }\end{array}$ & $\begin{array}{c}\text { P. } \\
\text { Comp. }\end{array}$ & Result \\
\hline \multirow{3}{*}{ G8 } & \multirow{3}{*}{$\begin{array}{l}\text { Jet filter } \\
\text { perfor- } \\
\text { mance is } \\
\text { not } \\
\text { optimal }\end{array}$} & $\begin{array}{l}\text { Solenoid } \\
\text { valve has } \\
\text { an error }\end{array}$ & $\mathrm{K}$ & $\begin{array}{c}0,683 \\
3\end{array}$ & \multirow{3}{*}{$\begin{array}{c}0,968 \\
2\end{array}$} \\
\hline & & $\begin{array}{l}\text { Less air } \\
\text { pressure }\end{array}$ & L & $\begin{array}{c}0,683 \\
3\end{array}$ & \\
\hline & & $\begin{array}{l}\text { Air hose is } \\
\text { broke }\end{array}$ & M & $\begin{array}{c}0,683 \\
3\end{array}$ & \\
\hline
\end{tabular}

seen at Table 3. The calculation result of probability value each component can be seen at Table 4.

The result of the assessment is to determine the possibility of a hammer mill machine fire that can occur within a year using the FTA cut set. 


\subsection{Determine the Fire Probability with FTA Cut Set}

The probability calculation of each basic event or component probability is based on data processing failure with component reliability approach. Then do the top event probability calculation by entering the probability of each basic event that has been obtained earlier on the formula or gate or and gate from the lowest failure tree level to the top or top event. The calculations can be seen in Table 5 .

Based on the overall result of fault tree analysis method, it is known that there are 48 minimum cut set cause of fire of hammer mill machine and based on total data of failure owned by company which calculated by using quantitative method of FTA obtained result that fire of hammer mill machine can happen with possibility equal to 0,4843 time per year.

\subsection{HRA Calculation with SPAR-H Method to Obtained HEP}

In this step, it only calculated in scenarios of safety procedures involving humans. HEP assessment by expert judgement and the calculation shows at Table 6 .

Table 6 HRA Calculation with SPAR-H Method

\begin{tabular}{|l|c|c|c|c|c|}
\hline Factor Multiplier & $\begin{array}{c}\text { The } \\
\text { operator } \\
\text { detects } \\
\text { smoke }\end{array}$ & $\begin{array}{c}\text { The } \\
\text { operator } \\
\text { turn off } \\
\text { SERA }\end{array}$ & $\begin{array}{c}\text { The operator } \\
\text { turn off the } \\
\text { breaker }\end{array}$ & $\begin{array}{c}\text { The operator } \\
\text { extinguished } \\
\text { the fire with } \\
\text { fire extingusher }\end{array}$ & $\begin{array}{c}\text { The operator } \\
\text { extinguished } \\
\text { the fire with } \\
\text { fire hydrant }\end{array}$ \\
\hline Available time & 1 & 1 & 1 & 1 & 1 \\
\hline Stress & 2 & 2 & 2 & 2 & 2 \\
\hline $\begin{array}{l}\text { Experience and } \\
\text { Training }\end{array}$ & 1 & 0,5 & 1 & 1 & 1 \\
\hline Complexity & 1 & 2 & 1 & 2 & 2 \\
\hline Ergonomics & 10 & 1 & 1 & 10 & 10 \\
\hline Procedure & 1 & 1 & 5 & 5 & 5 \\
\hline Fitness for duty & 1 & 1 & 1 & 1 & 1 \\
\hline Work Process & 1 & 0,8 & 1 & 1 & 1 \\
\hline PSF Composite & 20 & 1,6 & 10 & 200 & 200 \\
\hline NHEP(actions) & 0,001 & 0,001 & 0,001 & 0,001 & 0,001 \\
\hline NHEP(diagnosis) & 0,01 & 0,01 & 0,01 & 0,01 & 0,01 \\
\hline HEP(actions) & 0,01963 & 0,00160 & 0,00991 & 0,16681 & 0,16681 \\
\hline HEP(diagnosis) & 0,16807 & 0,01590 & 0,09174 & 0,66890 & 0,66890 \\
\hline HEP total & 0,18440 & 0,01748 & 0,10074 & 0,72413 & 0,72413 \\
\hline
\end{tabular}

\subsection{Combination Calculation of Component Failure with Human Error Probability}

At this stage, fire emergency response scenarios involving safety devices and human are analyzed using a combination of component failure and Human Error Probability (HEP) values. The value of component failure is taken from component probability calculation and HEP value is taken from Human Reliability Assessment (HRA) with SPAR-H method. The formula used in this calculation is the formula number (3) that is the formula to calculate the AND gate logic. The result of the combination calculation between component failure and HEP will be the value of success probability in ETA. FTA of each pivotal event can be seen in Table 7. 
Table 7 FTA Each Pivotal Event

\begin{tabular}{|c|c|c|c|c|}
\hline $\begin{array}{c}\text { Pivotal } \\
\text { Event }\end{array}$ & FTA & Cause & $\begin{array}{c}\text { Failure } \\
\text { Probability } \\
\text { Value }\end{array}$ & Result \\
\hline \multirow{2}{*}{$\begin{array}{c}\text { The } \\
\text { operator } \\
\text { turn off } \\
\text { the } \\
\text { breaker }\end{array}$} & \multirow[t]{2}{*}{ ato turns o o } & $\begin{array}{l}\text { Breaker } \\
\text { trouble }\end{array}$ & 0,6164 & \multirow{2}{*}{0,655} \\
\hline & & $\begin{array}{c}\text { Human } \\
\text { error }\end{array}$ & 0,10074 & \\
\hline \multirow{2}{*}{$\begin{array}{c}\text { The } \\
\text { operator } \\
\text { extingu- } \\
\text { ished } \\
\text { the fire } \\
\text { with fire } \\
\text { exti- } \\
\text { nguisher }\end{array}$} & \multirow[t]{2}{*}{ 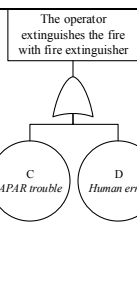 } & $\begin{array}{c}\text { Fire } \\
\text { extingu- } \\
\text { isher } \\
\text { trouble }\end{array}$ & 0,75 & \multirow{2}{*}{0,931} \\
\hline & & $\begin{array}{c}\text { Human } \\
\text { error }\end{array}$ & 0,72413 & \\
\hline \multirow{2}{*}{$\begin{array}{l}\text { The } \\
\text { operator } \\
\text { extingu- } \\
\text { ished } \\
\text { the fire } \\
\text { with fire } \\
\text { hydrant }\end{array}$} & \multirow[t]{2}{*}{ 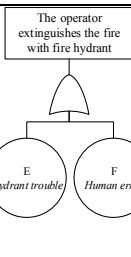 } & $\begin{array}{l}\text { Hydrant } \\
\text { trouble }\end{array}$ & 0,06 & \multirow[b]{2}{*}{0,7407} \\
\hline & & $\begin{array}{c}\text { Human } \\
\text { error }\end{array}$ & 0,72413 & \\
\hline
\end{tabular}

\subsection{Dependency}

From the result of the dependency factor, there are complete dependency found in 3 of 4 pivotal events or tasks involving humans in doing the work, which it means the dependency factors are good enough so it does not bring bad impact on the PSF results. The dependency factor can be seen at Table 8 . The task of Table 8 is the same task with Table 6 .

Table 8 Dependency Factor of Fire Emergency Response Scenario of Hammer Mill Machine

\begin{tabular}{|c|c|c|c|c|c|c|}
\hline Task & Crew & Time & $\begin{array}{c}\text { Loca- } \\
\text { tion }\end{array}$ & Cues & $\begin{array}{c}\text { Depen- } \\
\text { dency }\end{array}$ & Result \\
\hline 1 & $\mathrm{~S}$ & $\mathrm{c}$ & $\mathrm{S}$ & $\mathrm{na}$ & Complete & 1 \\
\hline 2 & $\mathrm{~S}$ & $\mathrm{c}$ & $\mathrm{D}$ & $\mathrm{a}$ & High & 0,50875 \\
\hline 3 & $\mathrm{~S}$ & $\mathrm{c}$ & $\mathrm{S}$ & $\mathrm{na}$ & Complete & 1 \\
\hline 4 & $\mathrm{~S}$ & $\mathrm{c}$ & $\mathrm{S}$ & $\mathrm{na}$ & Complete & 1 \\
\hline 5 & $\mathrm{~S}$ & $\mathrm{c}$ & $\mathrm{S}$ & $\mathrm{na}$ & Complete & 1 \\
\hline
\end{tabular}

\subsection{Event Tree Analysis of Hammer Mill Machine Fire Before Recommendation}

All calculated values above are entered into the probability value of each pivotal event of ETA. The ETA of hammer mill machine fire can be seen at Figure 5.

A : Sensor works

B : Temperature Safety Interlock System works

C : The operator detects smoke

D : The operator turn off SERA 
E : The operator turn off the breaker

$\mathrm{F}:$ The operator extinguished the fire with fire extingusher

$\mathrm{G}$ : The operator extinguished the fire with fire hydrant

Outcome I : Fire controlled

Outcome II : Fire uncontrolled

From Figure 4, the total probability of outcome I (fire controlled) is equal to 0,23192 and the total probability of outcome II (fire uncontrolled) is equal to 0,76808 .. We can see that the value of fire uncontrolled outcome is high, therefore it needs to be lowered by control based ALARP.

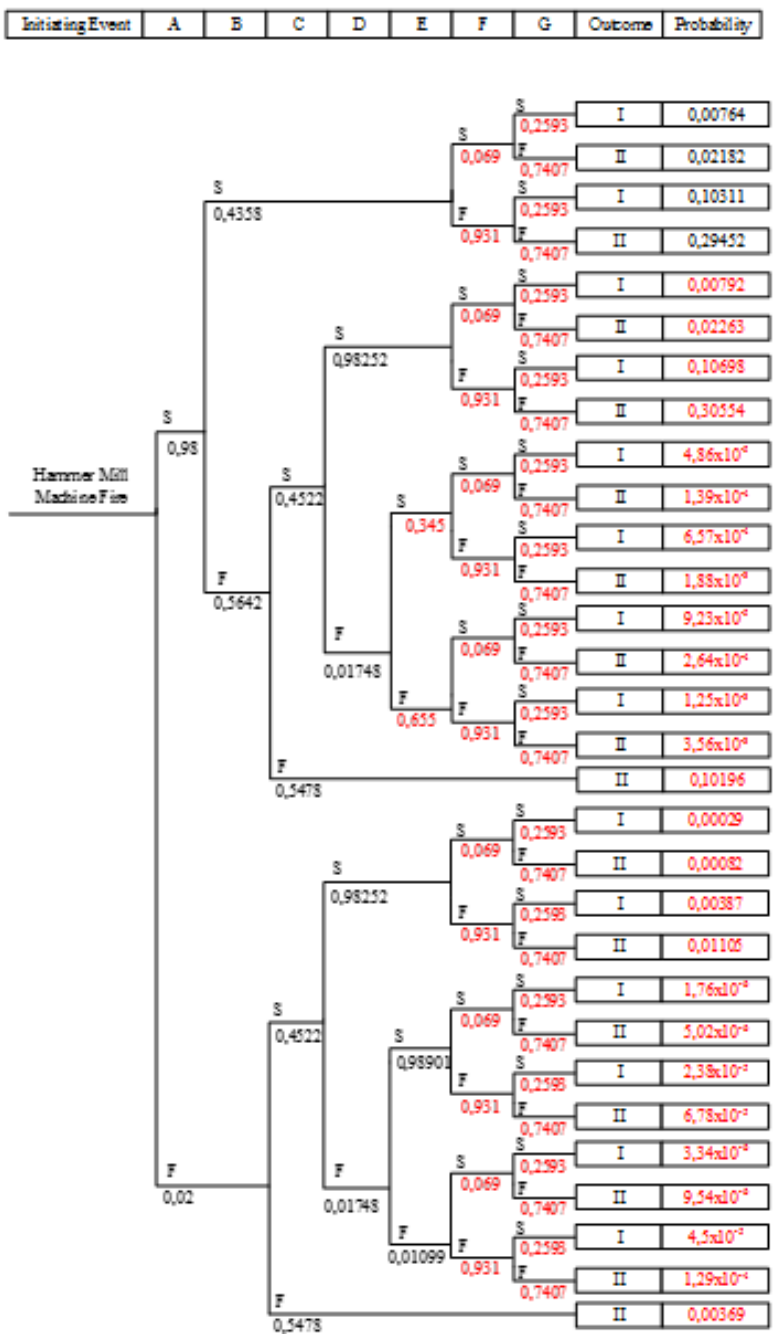

Fig. 4 Event Tree Analysis of Hammer Mill Machine Fire Before Recommendation 


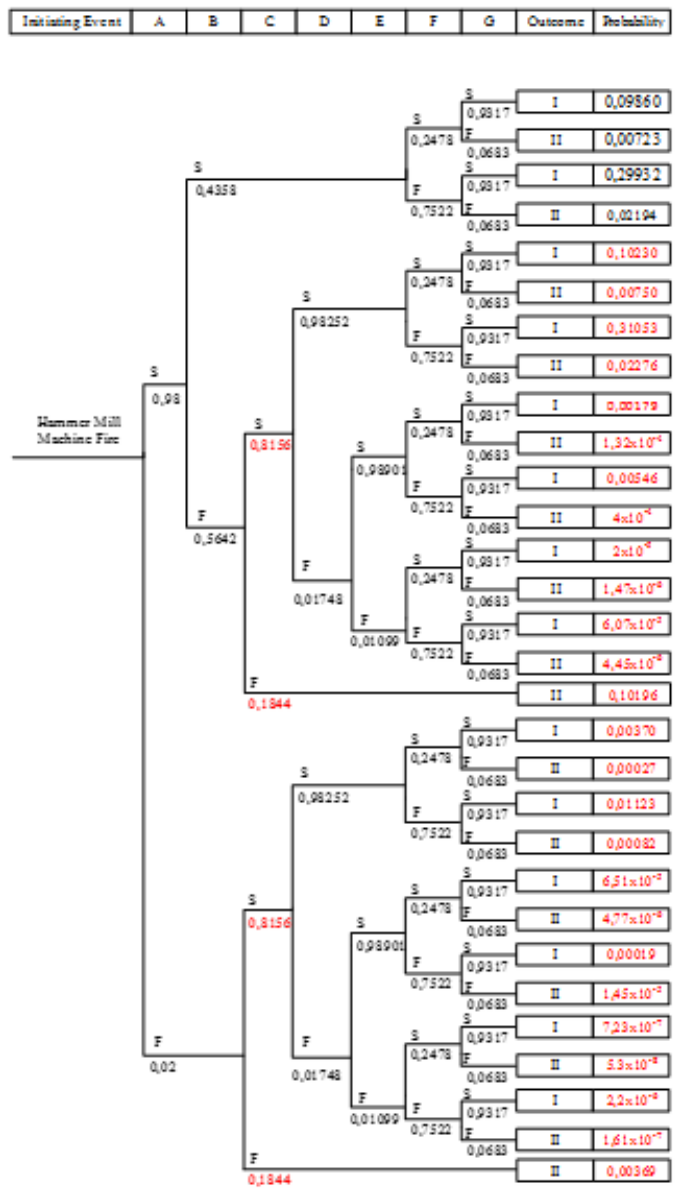

Fig. 5 Event Tree Analysis of Hammer Mill Machine Fire After Recommendation

\subsection{Recommendation}

The recommendation is undertaken to reduce the total probability value of uncontrolled fire outcomes and increase the total probability value of controlled fire outcomes.

First, the control is done on the existing safety device, whether the probability of success of each safety device can be raised or not. Safety device before the control that has a big probability of failure value, will be replaced with a new safety device therefore the probability of failure value becomes zero. The next step is controlling from the worker's side, that is from the work done by the workers. The work is identified and repaired using the SPAR-H method.

The result of ETA calculation after recommendation can be seen in the Figure 5. From Figure 5 above, the total probability of outcome fire controlled is equal to 0,83329 . This value increased from the previous value, that is 0.23192 . The total probability of outcome fire controlled is equal to 0,16671 . This value decreased from the previous value, that is 0,76808 .

The probability number does not go down until ALARP although it has been improved either from worker side or from safety device side. However, the increase of probability values in controlled fire outcome and the decrease of the probability value in the fire uncontrolled outcome are significant. If the controlling is desired until ALARP, the entire 
fire emergency response scenario is changed to be automatically performed by the safety device.

\section{Conclusion}

Based on the overall result of fault tree analysis method, it is known that there are 48 minimum cut set cause of fire of hammer mill machine and based on calculation by using quantitative method of FTA, obtained result that fire of hammer mill machine can happen with possibility equal to 0,4843 times per year. The total probability of outcome fire uncontrolled decreases from 0,76808 to 0,16671 . The probability number does not go down until ALARP although it has been improved either from worker side or from safety device side. The total probability of outcome fire uncontrolled decreases significantly, however, the decrease has not yet reached the ALARP level. Based on these findings, then to approach ALARP level, the company has to eliminate and replace human roles with machine automation, because this emergency response scenario mostly done by workers.

\section{References}

1. S.A. Roshan, S. Daneshvar, FRA. N. Its. Ecmc. Ls. Estm. In. Thrn. Sbwy. Aply. ETA. 2 (2014)

2. C. Wade, P. Whiting, FRA. Usng. Bdng. Fr. Sfty. Eng. Mthd. 8 (1997)

3. F. Liu, S. Zhao, M. Weng, Y. Liu, FRA. Lrg-scl. Cmrcl. Bdng. Bsd. Strc. Etrpy. Wght. Mthd. (2016)

4. Y.P. Wijaya, S.A.T. Noya, App. Of. FTA. SPAR-H. Mtd. To. Ctr. Wrk. Acdt. At. Pg. Krbt. Br. 15 (2016)

5. T. Nazari, A. Rabiee, A. Ramezani, HEP. Qntfct. Usng. SPAR-H. Mthd. Ttl. Loss. Of. Fdwtr (2018)

6. W. Yao, HRA. PSA. Usng. SPAR-H. Mthd. (2013)

7. Clifton A. Ericson, Hazard Analysis Techniques for System Safety, II (2005)

8. Charles E. Ebeling, An Introduction to Reliability and Maintainability Engineering (2003)

9. B. Kirwan, Human Reliability Assessment (1994)

10. D. Gertman, H. Blackman, J. Marble, J. Byers, C. Smith, The SPAR-H Human Reliability Analysis Method (2005) 